\title{
Comunicação de Pesquisas
}

Análise dos Processos de Comunicação em Projetos com Equipes Virtuais.

Pág.144

Implantação de um Modelo de Estudo Prospectivo: Um Estudo de Caso no Segmento de Painéis Tipo MDF, no Setor Madeireiro. Pág. 145

Proposta de Estruturação do Processo de Desenvolvimento de Produtos Para Empresas Prestadoras de Serviço de Telecomunicações. Pág.146 